\title{
Studies of the Mechanism of Pyridoxine-Responsive Homocystinuria
}

\author{
Margretta R. Seashore, Joseph L. Durant, and Leon E. Rosenberg ${ }^{[40]}$ \\ Division of Medical Genetics, Departments of Pediatrics and Medicine, Yale University \\ School of Medicine, New Haven, Connecticut, USA
}

\begin{abstract}
Extract
Pharmacologic doses of pyridoxine corrected plasma amino acid abnormalities in two boys ( $J K$ and $E Y$ ) with homocystinuria caused by cystathionine synthase deficiency. Pyridoxine responsiveness was dose-dependent but differed in the two patients. $J K$ required $25 \mathrm{mg}$ pyridoxine per day for correction of plasma methionine, homocystine, and cystine concentrations; $E Y$ required more than $50 \mathrm{mg}$ pyridoxine per day. Cystathionine synthase assays on extracts of cultured skin fibroblasts were carried out to explore this apparent clinical difference. Under basal conditions, synthase activity in extracts from both patients was less than $5 \%$ of normal. Addition of saturating concentrations of pyridoxal phosphate to the assay mixture stimulated synthase activity fourfold in extracts from $J K$ 's cells. No detectable increase in enzyme activity was noted in extracts of $E Y$ 's cells under identical conditions. These in vivo and in vitro differences suggest that $J K$ 's pyridoxine responsiveness is mediated by partial correction of his underlying synthase deficiency and that $E Y$ 's response to pyridoxine may be produced by another mechanism, perhaps stimulation of alternate pathways of sulfur-amino acid metabolism.
\end{abstract}

\section{Speculation}

Can pyridoxine responsiveness in homocystinuria always be equated with stimulation of defective cystathionine synthase activity? Our results suggest a negative answer to this question and emphasize the need for further clinical and biochemical investigation of such patients.

\section{Introduction}

Two years after the clinical description of homocystinuria in $1962[5,12]$, the enzymatic basis of the disease was demonstrated by Mudd et al. [24] who showed that cystathionine synthase activity was absent in the livers of homocystinuric patients. This deficiency, also demonstrated in cultured skin fibroblasts [34], leads to increased concentrations of methionine and homocystine in plasma and urine. The absence or markedly reduced concentration of cystine in these fluids reflects the fact that cystathionine synthase catalyzes one of the steps in the major degradative pathway by which methionine is converted to cystine and ultimately to its end product, inorganic sulfate [20] (Fig. 1). The relation between these biochemical findings and the clinical hallmarks of homocystinuria which include ectopia lentis, skeletal abnormalities, mental retardation, and thrombotic vascular disease is unknown.

Two forms of therapy have been tried in homocystinuria. Limitation of dietary methionine with administration of supplemental cystine has resulted in bio- 


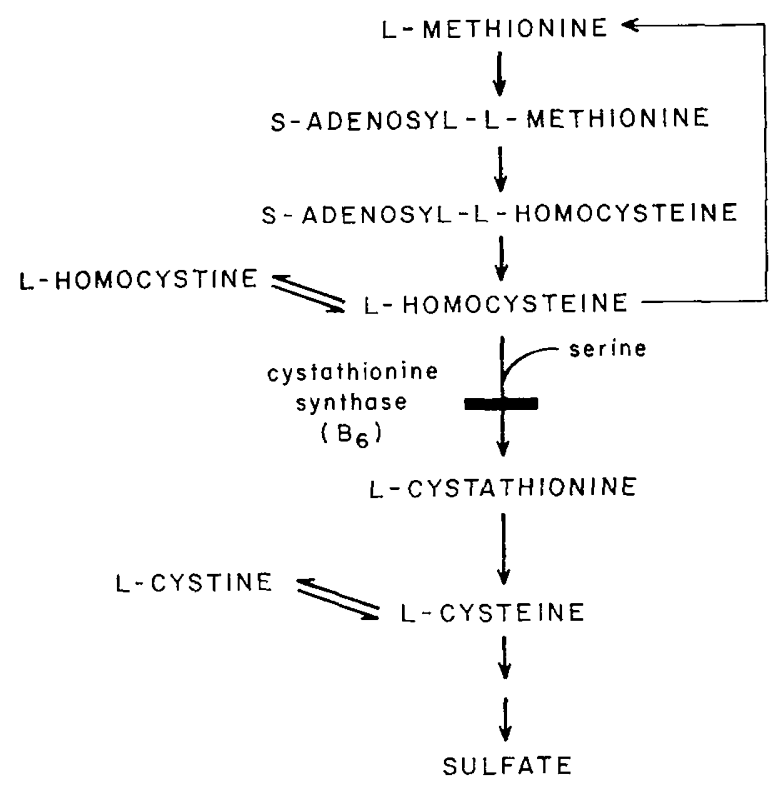

Fig. 1. Pathway of methionine catabolism to sulfate. In homocystinuria, methionine and homocystine accumulate because of an inherited deficiency of cystathionine synthase, the enzyme which catalyzes the condensation of serine and homocysteine to form cystathionine. Note that the enzymatic conversion of homocysteine to cystathionine appears to require vitamin $B_{6}$ in its coenzyme form (pyridoxal phosphate).

chemical improvement in several patients $[3,7,13,19$, 27], but it will require years to determine whether such improvement alters the clinical course of the disease. The second therapeutic approach, oral administration of pyridoxine, is based on the increasing, although not unequivocal, evidence that cystathionine synthase requires pyridoxal phosphate as a coenzyme $[4,18,26]$. Barber and Spaeth $[1,2]$ reported that plasma methionine and homocystine concentrations returned to normal in three patients given pharmacologic doses of pyridoxine (200-500 mg daily). This response, confirmed by other investigators $[10,15,16,33]$ in some but not all homocystinuria patients [16, 29], has also been associated with the appearance of cystine in plasma [11]. The biochemical basis for these findings is unclear. Yoshida et al. [35] reported that pyridoxal phosphate in vitro stimulated hepatic cystathionine synthase activity in one patient. Mudd and co-workers [23] observed that hepatic synthase activity in two pyridoxine-responsive patients was considerably greater when they were receiving pyridoxine than when they were not. Conversely, Hollowell [15], Gaull [11] and their co-workers found no such stimulation in other pyridoxine-responsive patients.

The present study was carried out to examine fur- ther the nature of pyridoxine-responsive homocystinuria. The effect of pyridoxine administration on plasma and urinary amino acid concentrations and urinary inorganic sulfate excretion was studied during normal dietary intake and under conditions of methionine loading. Cystathionine synthase activity in cell-free extracts of cultured skin fibroblasts was determined, and the influence of varying pyridoxine concentrations in the growth medium and of pyridoxal phosphate concentration in the in vitro assay system was studied. Our results suggest two different mechanisms of pyridoxine responsiveness in this disease.

\section{Patients}

Two young men, 16 and 18 years, with well documented homocystinuria were studied. $J K$ was an 18year-old white male with lenticular dislocation, mild pectus excavatum, kyphoscoliosis, and minimal osteoporosis. IQ as measured by the Wechsler Adult Intelligence Scale was 71 verbal, 88 performance. $E Y$ was a 16-year-old white male with lenticular dislocation, slight kyphoscoliosis, and mild intention tremor. IQ as measured by the Wechsler Adult Intelligence Scale was 70 , full scale. Neither patient was anemic or demonstrated signs of vitamin $\mathrm{B}_{6}$ deficiency. Both patients had positive urinary nitroprusside tests and increased plasma and urine concentrations of methionine and homocystine (Table I). Plasma cystine was undetectable in both [36].

During the study, the patients were hospitalized on a clinical research unit. Dietary intake of methionine and cystine, estimated by a dietitian, was kept constant, and was similar to that ingested at home (Table I). Informed consent from both patients was obtained in accordance with the provisions set forth in the Declaration of Helsinki.

Table I. Parameters of sulfur amino acid metabolism in two homocystinuric patients prior to pyridoxine administration

\begin{tabular}{|c|c|c|c|c|c|c|c|c|c|}
\hline \multirow[b]{2}{*}{$\underset{\text { tient }}{\mathrm{Pa}-}$} & \multicolumn{3}{|c|}{ Methionine } & \multicolumn{3}{|c|}{ Homocystine } & \multicolumn{3}{|c|}{ Cystine } \\
\hline & $\begin{array}{c}\text { Die- } \\
\text { tary } \\
\text { in- } \\
\text { take }\end{array}$ & $\begin{array}{c}\text { Plas- } \\
\text { ma } \\
\text { conc }{ }^{2}\end{array}$ & $\begin{array}{l}\text { Uri- } \\
\text { nary } \\
\text { excre- } \\
\text { tion }^{3}\end{array}$ & $\begin{array}{c}\text { Die- } \\
\text { tary } \\
\text { in- } \\
\text { take }\end{array}$ & $\begin{array}{c}\text { Plas- } \\
\text { ma } \\
\text { conc } c^{2}\end{array}$ & $\begin{array}{l}\text { Uri- } \\
\text { nary } \\
\text { excre- } \\
\text { tion }^{3}\end{array}$ & $\begin{array}{c}\text { Die- } \\
\text { tary } \\
\text { in- } \\
\text { taket }\end{array}$ & $\begin{array}{l}\text { Plas- } \\
\text { ma- } \\
\text { conc }{ }^{2}\end{array}$ & $\begin{array}{c}\text { Uri- } \\
\text { nary } \\
\text { excre- } \\
\text { tion }^{3}\end{array}$ \\
\hline$J K$ & 35.8 & 9.7 & 65 & 0 & 3.5 & 111 & 21.6 & 0 & 0 \\
\hline$E Y$ & 28.3 & 7.8 & 71 & 0 & 2.9 & 216 & 19.2 & 0 & 0 \\
\hline
\end{tabular}

${ }^{1}$ Milligrams per kilogram per day; calculated by a dietitian and kept constant during the study.

${ }^{2}$ Milligrams per $100 \mathrm{ml}$; value presented is representative of several fasting determinations.

${ }^{3}$ Milligrams per $24 \mathrm{hr}$; value is representative of several $24 \mathrm{hr}$ collections. 


\section{Methods}

\section{Effect of Pyridoxine on Sulfur Amino Acid Metabo- lism}

Pyridoxine hydrochloride was given daily, by mouth, in four divided doses. During administration of the $500-\mathrm{mg}$ daily dose, the patients were hospitalized for 2 weeks, and were then observed as outpatients for four consecutive months. The vitamin was then discontinued for 1 month. Subsequently, lower doses of pyridoxine were given for 2- to 3-week intervals and increased progressively. Fasting plasma amino acid concentrations were determined at each pyridoxine dose after 2-3 weeks. Oral loads of L-methionine were administered to both patients on two occasions: while on $500 \mathrm{mg}$ pyridoxine daily for four consecutive months, and after receiving no supplementary pyridoxine for 60 days. L-Methionine was given as the pure, crystalline amino acid in gelatin capsules, each containing $0.3 \mathrm{~g}$. The total daily methionine load of 0.75 mmole $/ \mathrm{kg}$ was given in four divided doses for 4 days, and was well tolerated.

Urine was collected, without preservative, for 24-hr periods, and kept refrigerated during collection. Aliquots were frozen and stored at $-20^{\circ}$ until analyzed. Heparinized blood was drawn in the morning after an overnight fast and centrifuged; the plasma was deproteinized immediatly by addition of an equal volume of $10 \%$ sulfosalicylic acid. The precipitate was removed by centrifugation and the deproteinized plasma was stored at $-20^{\circ}$ until analyzed.

Plasma and urinary amino acid concentrations were determined, using a Beckman 120C automatic amino acid analyzer, by the method of Spackman, Stein, and Moore [31]. Urinary inorganic sulfate was determined according to Fiske's method [14].

\section{Enzyme Assays in Cultured Skin Fibroblasts}

Skin fibroblasts were grown in tissue culture from a 4-mm skin biopsy. Standard diploid growth medium (Grand Island Biological), containing $1 \mathrm{mg}$ pyridoxine per liter was used for most studies. In some experiments, the diploid growth medium was supplemented with $100 \mathrm{mg}$ pyridoxine per liter. The cells were grown to confluence in Bellco roller bottles, and then were harvested with $0.5 \%$ trypsin, washed with $0.9 \%$ saline, and disrupted by sonication in $\mathrm{K}_{2} \mathrm{HPO}_{4}$ buffer, $\mathrm{pH} 6.9$, using a Branson Sonifier equipped with a microtip. The supernatant fluid obtained after centrifugation at $5000 \times g$ for $10 \mathrm{~min}$ was used for assay of cystathionine synthase activity. Protein concentration of this cell-free supernatant fluid was determined by the method of Lowry et al. [21]. Two different assay systems were employed. The first was the radioisotopic method of Mudd et al. [25, 34], in which the incorporation of serine- $3-{ }^{14} \mathrm{C}$ into cystathionine $-{ }^{14} \mathrm{C}$ was measured. This technique employed a serine concentration of $2.5 \mathrm{~mm}$ and required the addition of $0.07 \mu$ moles cystathionine to the reaction mixture. The labeled cystathionine formed during a 135-min incubation was identified by paper chromatography [25] and quantitated in a liquid scintillation spectrometer. Hepatic cystathionine synthase activity has been shown to be linear with time and enzyme concentration when assayed by this method [25]. Similarly, in our experiments, doubling the amount of control fibroblast cell extract led to a doubling of cystathionine formation. Boiled blanks were run daily for each cell line studied.

In the second method, cystathionine formation was quantitated by column chromatography on a Beckman 120C amino acid analyzer using the method of Scriver et al. [30]. The reaction mixture was identical with that employed for the isotopic method except that the serine concentration was increased to $25 \mathrm{~mm}$ and cystathionine was omitted. Boiled blanks for each cell line were run daily. After $135 \mathrm{~min}$ of incubation, the reaction mixture was deproteinized and eluted through a Dowex 50-X4 column exactly as described for the radio-isotopic assay. The eluate was then taken to dryness in a vacuum desiccator at room temperature, taken up in $1.0 \mathrm{ml} 0.2 \mathrm{~N}$ sodium citrate buffer ( $\mathrm{pH} 2.2)$, applied to a $22-$ by $0.9-\mathrm{cm}$ column of PA 35 resin and eluted at $60^{\circ}$ with a $0.1 \mathrm{~N}$ sodium citrate buffer $(\mathrm{pH}$ 3.6) delivered at a rate of $50 \mathrm{ml} / \mathrm{hr}$. Authentic cystathionine was eluted after $63 \mathrm{~min}$, and particular attention was paid to this localization to avoid confusion with pyridoxal phosphate adducts known to simulate cystathionine in other chromatographic systems [11]. A peak with the proper elution time for cystathionine was observed as a reaction product when cell extracts were incubated without added pyridoxal phosphate, but was not seen when boiled cell extracts were incubated with pyridoxal phosphate. Results of both enzyme assays are expressed as nanomoles cystathionine formed per milligram cell protein per $135 \mathrm{~min}$.

The $\mathrm{L}$-serine-3-14 $\mathrm{C}$ used in the isotopic assay was purchased from Amersham-Searle and was purified by column chromatography prior to use [25]. Pyridoxal-5'phosphate, purchased from Sigma Chemical Company, was stored in a vacuum desiccator at $-20^{\circ}$ and was prepared fresh daily immediately before use. L-Cys- 


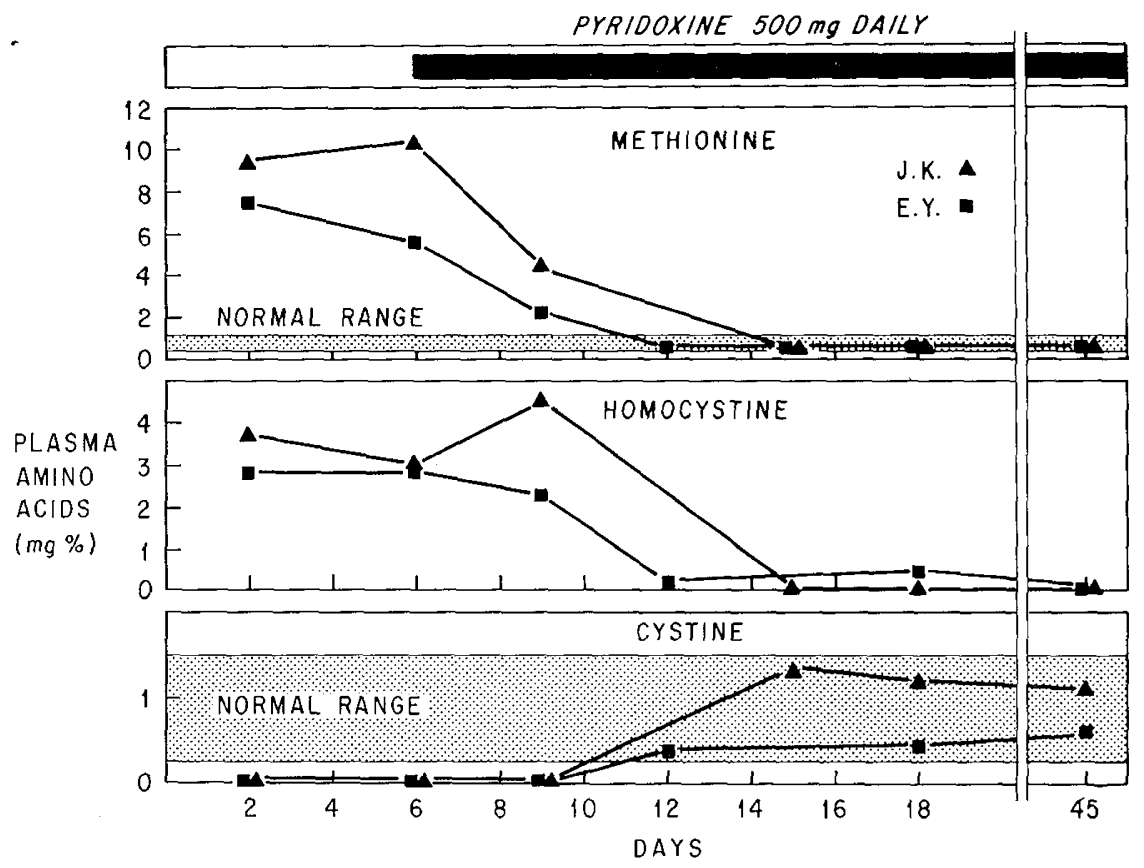

Fig. 2. Response of sulfur amino acid concentrations in plasma of homocystinuric patients $J K$ and $E Y$ to 500 mg pyridoxine daily. Not the fall in methionine and homocystine concentrations to normal. Cystine, initially absent from the plasma of both patients, appeared after 10-15 days of pyridoxine administration.

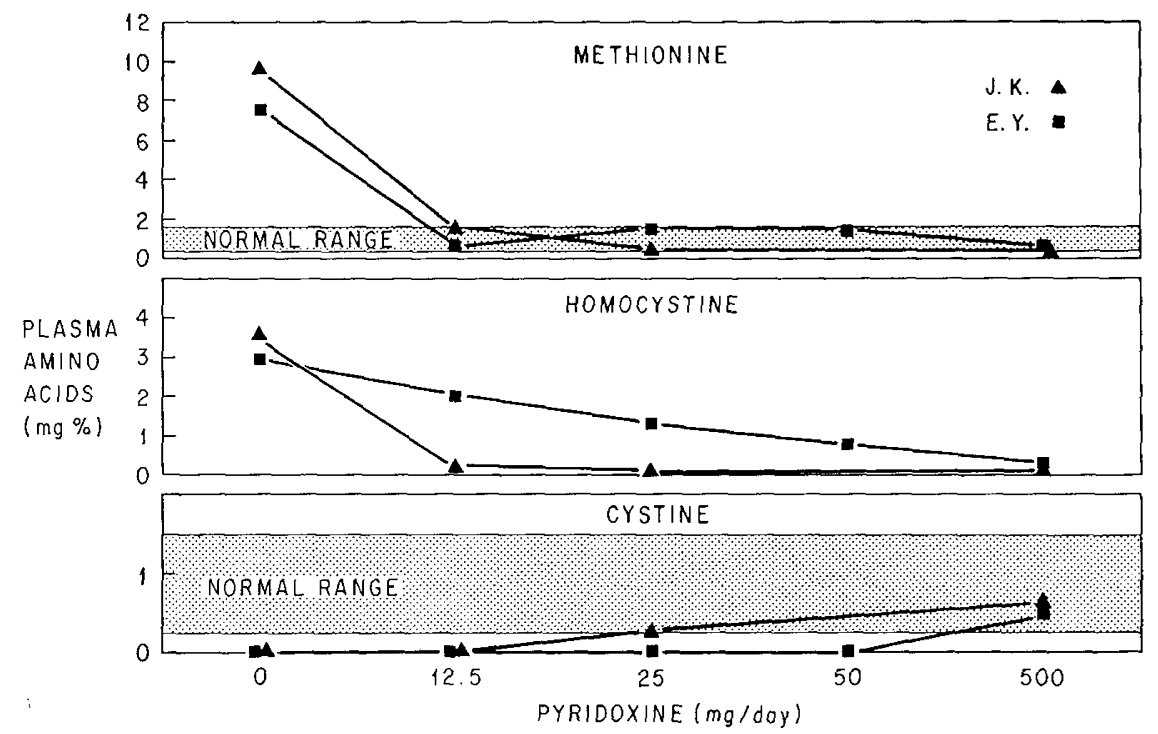

Fig. 3. Response of plasma amino acid concentrations to graded doses of pyridoxine. Note the substantial fall in plasma methionine concentration after only $12.5 \mathrm{mg}$ pyridoxine. In $J K$, methionine, homocystine, and cystine concentrations returned to normal after only $25 \mathrm{mg}$ pyridoxine daily. In $E X$, homocystine disappeared and cystine appeared at a pyridoxine dose of $500 \mathrm{mg}$ daily. 
tathionine was purchased from Sigma Chemical Company and from Calbiochem.

\section{Results}

\section{Effect of Pyridoxine on Amino Acids in Plasma and} Urine

Prior to pyridoxine administration, each patient had distinctly increased concentrations of methionine and homocystine and undetectable amounts of cystine in plasma (Table $\Upsilon$ and Fig. 2). Within 6 days of starting pyridoxine (500 mg/day), methionine and homocystine concentrations fell to normal values and cystine appeared. Urinary amino acid concentrations followed a similar pattern, except that in $E Y$, urinary homocystine never fell below $15.5 \mathrm{mg} / 24 \mathrm{hr}$.

When pyridoxine was discontinued, the plasma and urinary methionine and homocystine concentrations returned to their previous abnormal values, and cystine disappeared. The correction to normal occurred again when pyridoxine was readministered. No significant changes were noted in other normally occurring plasma or urinary amino acids, but the unusual sulfur amino acids described in plasma and urine of homocystinuric patients were not identified.

A dose-dependent response to pyridoxine was noted when graded doses from $12.5 \mathrm{mg}$ to $500 \mathrm{mg}$ were given (Fig. 3). In this respect, the two patients seemed to differ. Plasma methionine fell into the normal range in both patients at a pyridoxine dose of $12.5 \mathrm{mg}$. In $J K$, methionine and homocystine concentrations returned to normal after only $25 \mathrm{mg}$ pyridoxine, and cystine appeared in the plasma. In $E Y$, however, homocystine was still present in plasma at a pyridoxine dose of $50 \mathrm{mg} /$ day and cystine was absent. These abnormalities disappeared when he was given $500 \mathrm{mg}$ pyridoxine daily.

\section{Methionine Loading}

Oral methionine loading was carried out in the presence and absence of pyridoxine supplementation. Amino acid excretion during loading differed markedly in the two patients (Fig. 4). Pyridoxine had little effect on $E Y$ 's methionine output, which increased during loading, and receded only slowly after the load ended. In $J K$, methionine output during pyridoxine administration was only $30 \%$ of that without pyridoxine, and homocystine excretion followed a similar pattern. The fall in homocystine excretion observed during methionine loading in $E Y$ occurred with and without pyridoxine and is unexplained.
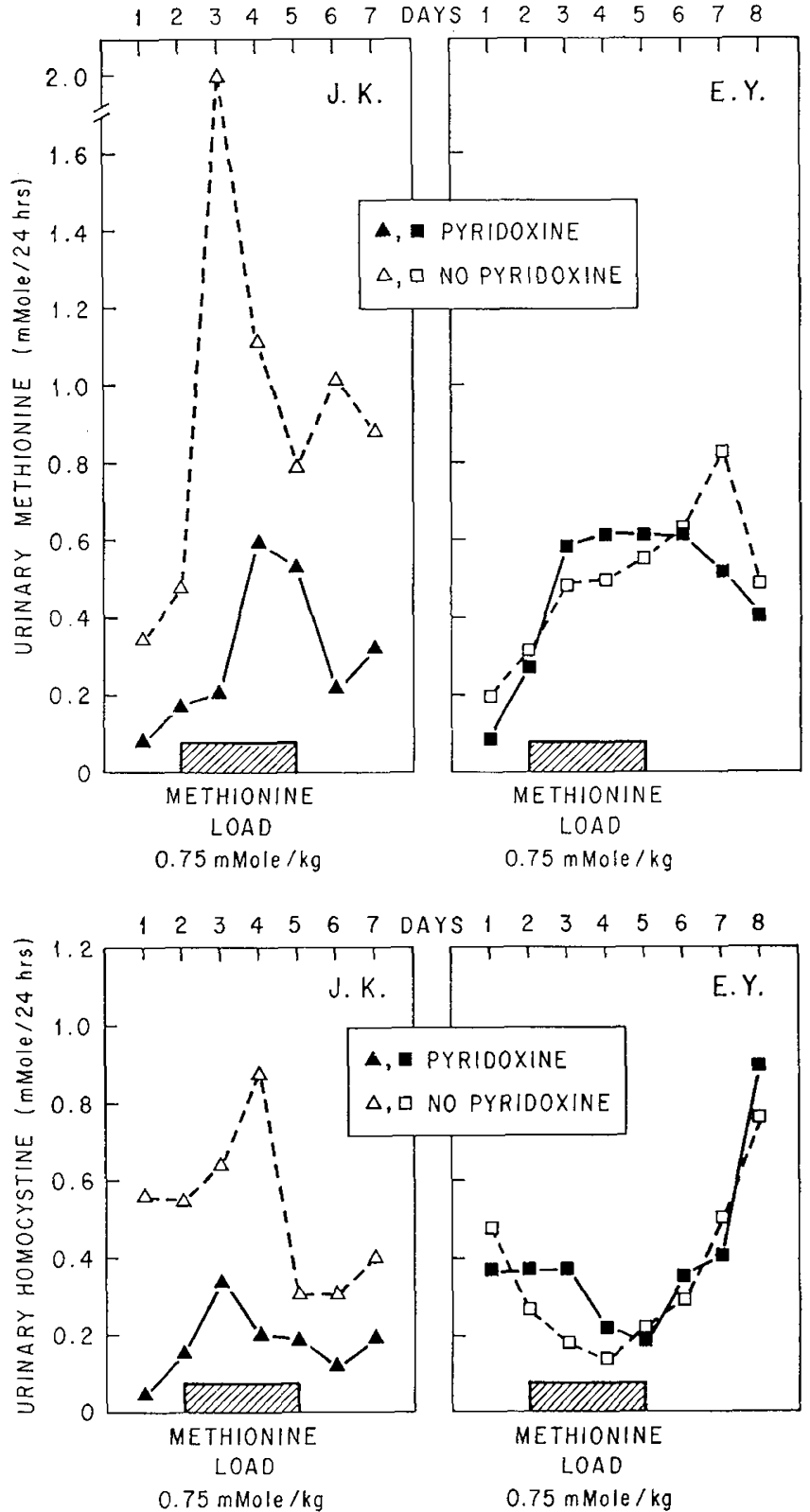

Fig. 4. Effect of pyridoxine (500 $\mathrm{mg}$ daily) on urinary excretion of methionine (upper) and homocystine (lower) after methionine loading. In $J K$, pyridoxine lowered basal excretion of both amino acids and resulted in a smaller increase during loading. In $E Y$, pyridoxine produced only a small difference in basal excretion and did not modify the response to the methionine load.

\section{Inorganic Sulfate Excretion}

Since the cystathionine synthase pathway has been considered important in the catabolism of methionine sulfur to its excretory product, sulfate, a change in urinary inorganic sulfate concentration after methionine loading was also sought. As shown in Figure 5, a 


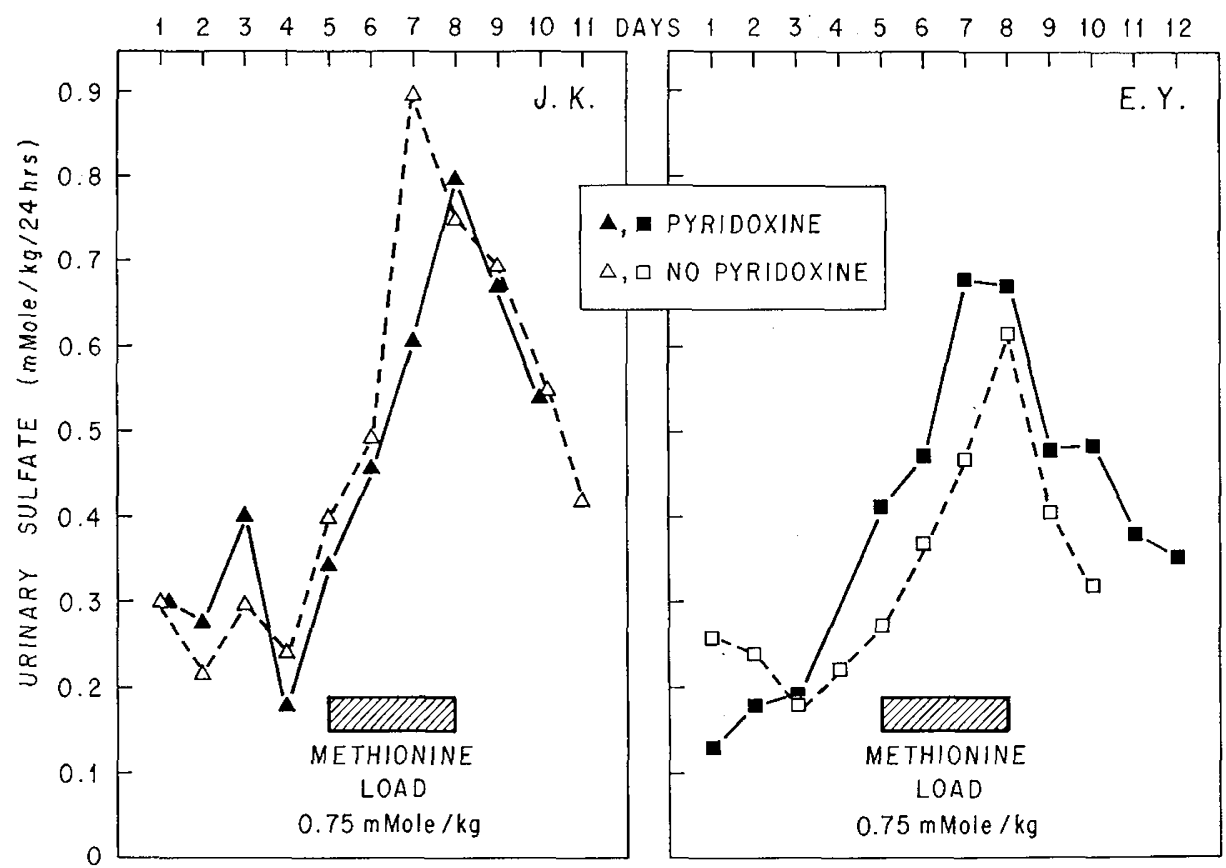

Fig. 5. Effect of pyridoxine on urinary inorganic sulfate excretion during methionine loading. No significant differences were seen in either patient.

rise in sulfate excretion did occur in both patients during loading, but this rise did not account for the entire methionine intake and did not change significantly during pyridoxine administration in either patient.

\section{Cystathionine Synthase Activity}

With the radioisotopic method, cystathionine synthase activity in cell-free extracts of cultured skin fi- broblasts from $E Y$ or $J K$ was barely detectable when compared with values in cell extracts from several controls (Table II). When small amounts of pyridoxal phosphate $(0.04 \mathrm{~mm})$ were used in the in vitro system, no stimulation of synthase activity was observed in control cell extracts (Table II), whereas pyridoxal phosphate concentrations of 1 and $5 \mathrm{~mm}$ did stimulate activity modestly $(0.05<P<0.1)$. In fibroblasts from $E Y$ there was no statistically significant increase in cys-

Table II. Cystathionine synthase activity by radioisotopic assay in cultured skin fibroblasts from control and homocystinuric patients ${ }^{1}$

\begin{tabular}{|c|c|c|c|c|c|}
\hline \multirow{2}{*}{ Patient } & \multicolumn{5}{|c|}{ Conc of pyridoxal phosphate in vitro } \\
\hline & 0 & $0.04 \mathrm{~mm}$ & $1.0 \mathrm{~mm}$ & $5.0 \mathrm{mM}$ & $10.0 \mathrm{mM}$ \\
\hline Controls & $\begin{array}{c}6.4 \pm 3.6^{2}(17)^{3} \\
(2.1-11.1)^{4}\end{array}$ & $\begin{array}{c}7.4 \pm 4.0(14) \\
(2.6-18.0)\end{array}$ & $\begin{array}{c}9.6 \pm 6.2(15) \\
(2.4-24.4)\end{array}$ & $\begin{array}{c}12.6 \pm 5.9(6) \\
(4.3-21.1)\end{array}$ & \\
\hline$E Y$ & $\begin{array}{ll}0.1 & (13) \\
& (0-0.6)\end{array}$ & $\begin{array}{l}0.3 \quad(6) \\
\quad(0-1.0)\end{array}$ & $\begin{array}{l}0.2 \quad(7) \\
\quad(0-0.8)\end{array}$ & $\begin{array}{l}0.3(10) \\
\quad(0.1-0.6)\end{array}$ & $\begin{array}{l}0.1 \quad 3) \\
(0-0.2)\end{array}$ \\
\hline$J K$ & $\begin{array}{ll}0.3 \quad(11) \\
\\
\quad(0-0.8)\end{array}$ & $\begin{array}{l}0.6(3) \\
\quad(0.4-0.9)\end{array}$ & $\begin{array}{l}1.4(15)^{5} \\
\quad(0.8-2.8)\end{array}$ & $\begin{array}{l}1.4(3)^{5} \\
\quad(1.2-1.8)\end{array}$ & \\
\hline
\end{tabular}

1 Synthase activity expressed as nanomoles cystathionine formed per milligram protein per 135 min. Enzyme activity in extracts of control, $E Y$, and $J K$ cells in the absence of added pyridoxal phosphate was compared with their corresponding activities in the presence of added pyridoxal phosphate $(0.04,1,5$, or $10 \mathrm{~mm})$. Only extracts of $J K$ cells revealed a statistically significant difference $(P<$ 0.05 ) at pyridoxal phosphate concentrations of 1 and $5 \mathrm{~mm}$, respectively. Standard deviation for results with extracts of $E Y$ and $J K$ cells was not calculated because numerous zero values were observed.

${ }^{2}$ Mean \pm standard deviation.

${ }^{3}$ Number of observations.

${ }^{4}$ Range.

${ }^{5} P<0.01$ compared with value of $0 \mathrm{~mm}$ pyridoxal phosphate. 
tathionine synthase at pyridoxal phosphate concentrations of 1,5 , or $10 \mathrm{~mm}$ (Fig. 6). Extracts from $J K$ 's cells, however, showed a consistently measurable, statistically significant fourfold increase in synthase activity at pyridoxal phosphate concentrations of $1 \mathrm{~mm}$ and $5 \mathrm{~mm}$ (Table II, Fig. 6).

These findings were confirmed by the column chromatographic assay. In control cell extracts, cystathionine formation was $18 \mathrm{nmoles} / \mathrm{mg}$ protein/135 min. In cell extracts from $J K, 1.9$ nmoles cystathionine/mg protein/135 min were formed without added pyridoxal phosphate, and addition of $1 \mathrm{~mm}$ pyridoxal phosphate to the incubation mixture increased cystathionine formation to 4.9 nmoles $/ \mathrm{mg}$ protein/135 min. Pyridoxal phosphate was without effect on $E Y$, whose extracts catalyzed the synthesis of less than I nmole cystathionine synthesis with or without added pyridoxal phosphate. No cystathionine was formed when cell extracts from controls, $E Y$, or $J K$ were boiled prior to use.

When synthase assays were performed on cells grown in culture medium supplemented 100 -fold with pyridoxine, enzyme activity in $E Y^{\prime}$ 's cell extracts was not enhanced even after three generations, nor was any consistent stimulation noted in $J K$ 's extracts unless 1 $\mathrm{mm}$ or $5 \mathrm{~mm}$ concentrations of pyridoxal phosphate were used in the in vitro assay system.

\section{Discussion}

In this study, two homocystinuric patients responded to pharmacologic doses of pyridoxine with in vivo biochemical improvement. The minimal effective dose could not be defined exactly, but, in both cases, was greater than 20 times the accepted normal daily requirement ( $1 \mathrm{mg}$ ).

Three kinds of evidence suggest that the mechanism of pyridoxine responsiveness differs in these two patients. First, the dose of pyridoxine required to return plasma amino acids to normal was lower in $J K$ than in $E Y$. Since the total body pools of methionine and homocystine were not measured, one could argue that the observed dose differences reflected differences in pool size rather than differences in mechanism. This argument, however, cannot account for the observation that cystine appeared in $J K$ 's plasma when he was given $25 \mathrm{mg}$ pyridoxine daily whereas cystine was not seen in $E Y$ 's plasma until he received $500 \mathrm{mg}$ pyridoxine per day. Second, pyridoxine modified amino acid excretion after methionine loading in $J K$ but not in $E Y$. Third, pyridoxal phosphate in high concentrations

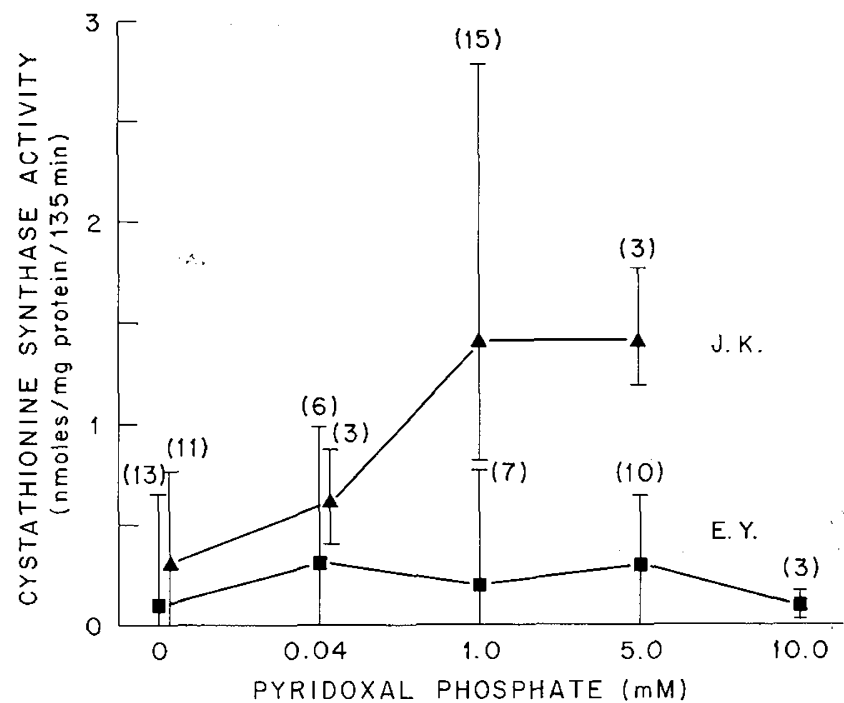

Fig. 6. Effect of increasing concentrations of pyridoxal phosphate on cystathionine synthase activity determined by radioisotopic assay in extracts of skin fibroblasts from $J K$ and $E Y$. The increasc in enzymatic activity in $J K$ 's cells at pyridoxal phosphate concentrations of $1 \mathrm{~mm}$ and $5 \mathrm{~mm}$ is statistically significant $(P<$ 0.01 ). No increased activity was seen in $E Y$ 's cells even at a pyridoxal phosphate concentration of $10 \mathrm{~mm}$. Values are shown as mean and range of number of observations is noted in parentheses.

stimulated cystathionine synthase activity in extracts of JK's fibroblasts, but no such enhancement was noted in extracts of $E Y$ 's cells. Since synthase activity in extracts of $E Y$ 's cells was often not detectable by the radioisotopic assay, it is possible that pyridoxal phosphate stimulated activity slightly to values still below the limits of detection by this assay system. We cannot exclude this possibility, but we believe that it is unlikely since the chromatographic assay did demonstrate detectable cystathionine formation by $E Y$ 's fibroblast extracts which was not increased by pyridoxal phosphate.

Several workers have examined the effect of pyridoxine on hepatic synthase activity in pyridoxine-responsive homocystinuric patients. Hollowell et al. [15] found no increase in hepatic synthase activity in two pyridoxine-responsive homocystinuric patients receiving pyridoxine orally. Gaull and his colleagues [11] obtained liver biopsies from five patients before and during pyridoxine therapy, and added pyridoxal phosphate in vitro to two samples. Again, no increase in synthase activity was found. Another pyridoxine-responsive patient was studied by Yoshida et al. [35] after withdrawing pyridoxine for several weeks. In contrast to the findings cited above, synthase activity 


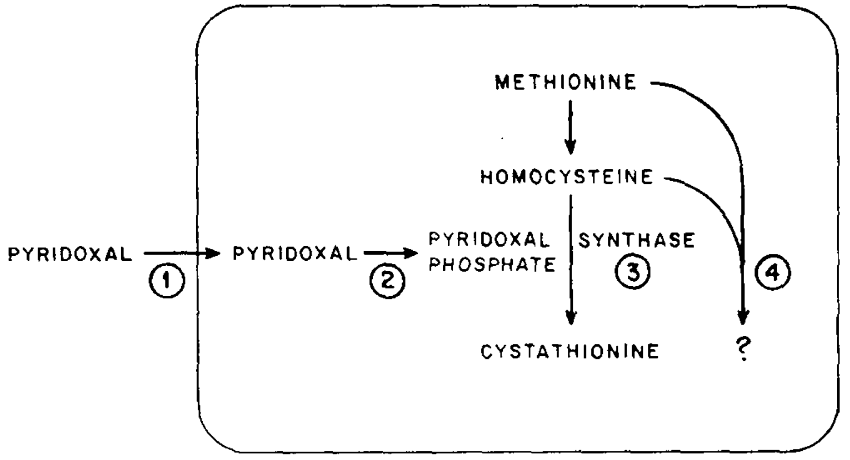

Fig. 7. Schematic illustration of possible biochemical mechanisms of pyridoxine responsiveness in homocystinuria. The continuous heavy black line designates the cell membrane. The several sites designated $1,2,3,4$ are discussed in the text in detail.

was increased significantly when pyridoxal phosphate was added in excess in vitro. Recently, Mudd and his colleagues [23] also reported that synthase activity in two pyridoxine-responsive patients was significantly greater when they were receiving pyridoxine than when no supplements were being given. Thus, it seems that cystathionine synthase activity in liver or cultured fibroblasts may be increased by pyridoxal phosphate in some, but not all, pyridoxine-responsive homocystinuric patients.

Several mechanims have been proposed to explain responsiveness to pharmacologic amounts of vitamin cofactors in inherited diseases [28]. These are shown schematically in Figure 7 with reference to the situation in homocystinuria. Abnormal transport of pyridoxine into the cell (site 1) does not explain pyridoxine responsiveness because no other pyridoxine-dependent functions are disturbed. Similarly, inasmuch as pyridoxal phosphate is the only known coenzyme form of pyridoxine, deranged conversion of the vitamin to active coenzyme (site 2) cannot explain the findings.

If a mutation of the cystathionine synthase apoenzyme reduced its affinity for its putative coenzyme, pyridoxal phosphate, enzyme activity could be enhanced by large excesses of the cofactor (site 3). Pyridoxal phosphate could also act by stabilizing a modified synthase apoenzyme. Examples of such correction seem to explain the findings in the pyridoxine-responsive forms of cystathioninuria [9] and xanthurenic aciduria [32], and may explain the results reported herein for $J K$. Because no increase in enzyme activity was observed in extracts from $E Y$ 's cells, however, another mechanism must be considered, namely, the stimulation or activation of alternate pathways of sulfur amino acid utilization (site 4).

Some alternate pathways of methionine and homocysteine metabolism are shown in Figure 8. Bacteria

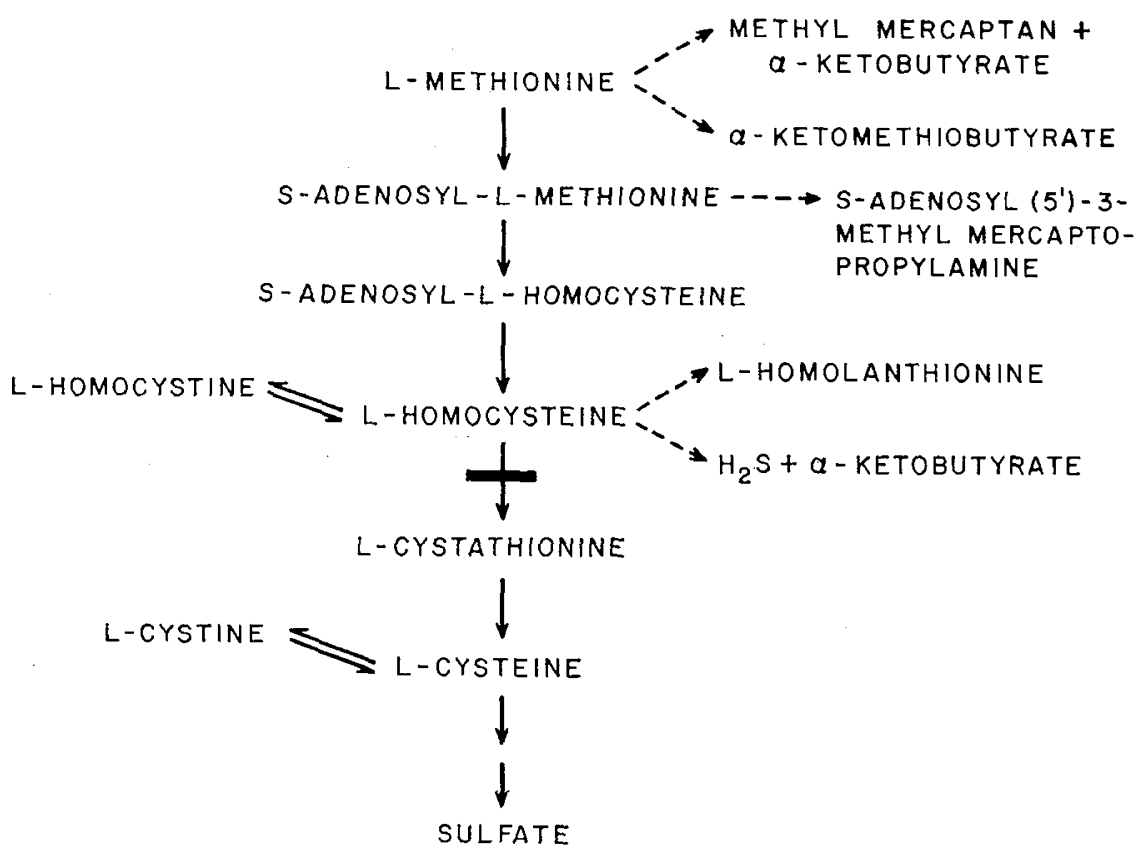

Fig. 8. Pathways of methionine metabolism. The major pathway is designated by solid arrows with the block in homocystinuria. Suggested alternate pathways are noted with broken arrows. The relation between these pathways and pyridoxine responsiveness is discussed in the text. 
contain pyridoxal-dependent enzymes which convert methionine to $\alpha$-ketobutyrate [22] or $\alpha$-aminobutyrate [6] and which decarboxylate $S$-adenosyl-methionine to $S$-adenosyl-(5')-3-methylmercaptopropylamine [22]. Some of these reactions are also known to occur in mammalian tissues [22] but their pyridoxal dependence has not been verified. Similarly, homocysteine desulfhydrase, present in mammalian liver, requires pyridoxal phosphate in microorganisms [17]. Stimulation of any or all of these pathways could explain the biochemical correction in homocystinuric patients like $E Y$ whose cystathionine synthase activity is unaffected by even massive amounts of pyridoxal phosphate. Other workers have looked for $\alpha$-ketobutyrate and $\alpha$-ketomethiobutyrate in urine of pyridoxine-responsive homocystinurics without success [20]. Similarly, urinary $\alpha$-aminobutyrate has not been noted in increased amounts by others [20] or ourselves. Thus, no positive evidence for alternate pathway stimulation has been obtained to date. Nonetheless, since the products of such alternate pathways could be toxic, additional studies are needed to define the nature of the biochemical response. Furthermore, it must be shown that the in vivo biochemical improvement in such pyridoxineresponsive patients produces therapeutic benefits, or is at least not associated with deleterious consequences.

Many workers have called attention to the genetic heterogeneity noted in human inborn errors of metabolism [8]. Evidence for such heterogeneity has come from studies of the abnormal enzymes, analysis of pedigrees, and investigation of heterozygotes. Vitamin responsiveness is yet another way of identifying genetic heterogeneity. Three kinds of homocystinuria are suggested by these and previous studies. These include a pyridoxine-unresponsive form, and two pyridoxine-responsive forms: one in which cystathionine synthase activity is stimulated by the vitamin and one in which it is not.

\section{Summary}

Detailed in vivo and in vitro investigations of two young men with pyridoxine-responsive homocystinuria suggest that responsiveness in one patient was mediated by stimulation of defective cystathionine synthase activity and in the second patient by enhancement of alternate pathways of sulfur-amino acid metabolism.

\section{References and Notes}

1. Barber, G. W., ANd Spaeth, G. L.: Pyridoxine therapy in homocystinuria. Lancet, $i$ : 337 (1967).
2. Barber, G. W., and Spaeth, G. L.: The successful treatment of homocystinuria with pyridoxine. J. Pediat., 75: 463 (1969).

3. Brenton, D. P., Cusworth, D. C., Dent, C. E., and Jones, E. E.: Homocystinuria. Clinical and dietary studies. Quart. J. Med., 35: 325 (1966).

4. Brown, C., Brenner, C., And Gordon, P. H.: Cystathionine synthase. Fed. Proc., 27: 782 (1968).

5. Carson, N. A. J., Cusworth, D. C., Dent, C. E., Field, C. M. B., Neill, D. W., ANd Westall, R. G.: Homocystinuria: a new inborn error of metabolism associated with mental deficiency. Arch. Dis. Childhood, 38: 425 (1963).

6. Challenger, F., and Walshe, J. M.: Methyl mercaptan in relation to fetor hepaticus. Biochem. J., 59: 372 (1955).

7. Chase, H. P., Goodman, S. I., and O'Brien, D.: Treatment of homocystinuria. Arch. Dis. Childhood, 42: 514 (1967).

8. Childs, B., and Der Kaloustian, V. M.: Genetic heterogeneity. New Engl. J. Med., 279: 1205, 1267 (1968).

9. FrImpter, G.: Cystathioninuria: nature of defect. Science, 149: 1095 (1965).

10. Gaull, G. E., Rassin, D. K., And Sturman, J. A.: Pyridoxinedependency in homocystinuria. Lancet, $i i$ : 1302 (1968).

11. Gaulx, G. E., Rassin, D. K., and Sturman, J. A.: Enzymatic and metabolic studies of homocystinuria: effects of pyridoxine. Neuropadiatrie, 1: 199 (1969).

12. Gerritsen, T., Vaughn, J. G., And Waisman, H. A.: The identification of homocystine in the urine. Biochim. Biophys. Res. Comm., 9: 493 (1962).

13. Hambraeus, L., Wranne, L., and Larentsson, R.: Biochemical and therapeutic studics in two cases of homocystinuria. Clin. Sci., 35: 457 (1968).

14. Hawk, P. B., Oser, B. L., And Summerson, W. H.: Practical Physiological Chemistry, Ed. 13, p. 949. (Blakiston, New York, 1954).

15. Hollowell, J. G., Coryell, M. E., Hall, W. K., Findley, J. K., AND Thevaos, T. G.: Homocystinuria as affected by pyridoxine, folic acid and vitamin $B_{12}$. Proc. Soc. Exp. Biol. Med., 129: 327 (1968).

16. Hooft, C., Carton, D., and Samyn, W.: Pyridoxine treatment in homocystinuria. Lancet, $i$ : 1384 (1967).

17. Kallio, R. E.: Function of pyridoxal phosphate in desulfhydrase systems of Proteus morganii. J. Biol. Chem., 191: $371(1951)$.

18. Kashiwamata, S., and Greenberg, D. M.: Highly purified cystathionine synthase of rat liver. Fed. Proc., 28: 668 (1969).

19. Komrower, G. M., Lambert, A. M., Cusworth, D. C., AND Westall, R. G.: Dietary treatment of homocystinuria. Arch. Dis. Childhood, $41: 666$ (1966).

20. Laster, L., Mudd, S. H., Finkelstein, J. D., And Irreverre, F.: Homocystinuria due to cystathionine synthase deficiency: the metabolism of L-methionine. J. Clin. Invest., 44: 1708 (1965).

21. Lowry, O. H., Rosebrough, N. J., Farr, A. L., ANd Randall, R. J.: Protein measurement with the folin phenol reagent. J. Biol. Chem., 193: 265 (1951).

22. Meister, A.: Biochemistry of the Amino Acids, Ed. 2, Vol. 2. (Academic Press, New York, 1965).

23. Mudd, S. H., Edwards, W. A., Loeb, P. M., Brown, M. S., AND LASTER, L.: Homocystinuria due to cystathionine synthase deficiency: the effect of pyridoxine. J. Clin. Invest., 49: $1762(1970)$.

24. Mudd, S. H., Finkelstein, J. D., Irreverre, F., and Laster, 
L. P.: Homocystinuria: an enzymatic defect. Science, 143: 1443 (1964).

25. Mudd, S. H., Finkelstein, J. D., Irreverre, F., ANd Laster, L.: Transsulfuration in mammals. J. Biol. Chem., 240: 4382 (1965).

26. Nakagawa, H., and Kimura, H.: Purification and properties of cystathionine synthase from rat liver: separation of cystathionine synthase from serine dehydratase. Biochim. Biophys. Res. Comm., 32: 208 (1968).

27. Perry, T. L., Hansen, S., Love, D. L., Crawford, L. E., and TISCHLER, B.: Treatment of homocystinuria with a low methionine diet, supplemental cystine, and a methyl donor. Lancet, $i i$ : 474 (1968).

28. RoSENBERG, L. E.: Inherited aminoacidopathies demonstrating vitamin dependency. New Engl. J. Med., 281: 145 (1969).

29. Schimke, R. N., McKusick, V. A., ANd Weilbaecher, R. G.: Homocystinuria. In: W. L. Nyhan: Amino Acid Metabolism and Genetic Variation, p. 297. (McGraw-Hill, New York, 1967).

30. Scriver, C. R., Davies, E., ANd Lamm, P.: Accelerated selective short column chromotography of neutral and acidic amino acids on a Beckman-Spinco Analyzer, modified for simultaneous analysis of two samples. Clin. Biochem., 1: 179 (1968).

31. Spackman, D. H., Stein, W. H., and Moore, S.: Automatic recording apparatus for use in the chromatography of amino acids. Anal. Chem., 30: 1190 (1958).

32. Tada, K., Yokoyama, Y., Nakagawa, H., Yoshida, T., and Arakawa, T.: Vitamin $B_{6}$ dependent xanthurenic aciduria. Tohoku J. Exp. Med., 93: 115 (1967).

33. Turner, B.: Pyridoxine treatment in homocystinuria. Lancet, ii: 1151 (1967).
34. Uhlendorf, B. W., ANd Mudd, S. H.: Cystathionine synthase in tissue culture derived from human skin: enzyme defect in homocystinuria. Science, 160: 1007 (1968).

35. Yoshida, T., Tada, K., Yokoyama, Y., and ARakawa, T.: Homocystinuria of vitamin $B_{6}$ dependent type. Tohoku J. Exp. Med., 96: 235 (1968).

36. Further clinical details and other plasma and urine amino acid values are available on request from Dr. Seashore (current address: Department of Pediatrics, University of Florida, Gainesville, Fla. 32601, USA).

37. We are indebted to the dietitians and the nurses who provided diligent and devoted care to the patients while they were hospitalized on the Clinical Research Ward. We also want to thank Mrs. Mildred Stambaugh and Miss Virginia Steen for valuable technical assistance.

38. This work was presented in part at the annual meeting of the Society for Pediatric Research, May 1, 1970.

39. Supported by research grants from the John A. Hartford Foundation and the National Institutes of Health (AM 09527 and AM 12579), and by a clinical center grant from the National Institutes of Health (FR 00125). Dr. Seashore was supported by Training Grant no. HD 00198 from the National Institute of Child Health and Human Development, and Dr. Rosenberg was supported by Research Career Development Award no. AM 28987 from the National Institute of Arthritis and Metabolic Diseases.

40. Requests for reprints should be addressed to: LEON E. RosenBERG, M.D., Departments of Pediatrics and Medicine, Yale University School of Medicine, 333 Cedar Street, New Haven, Conn. 06510 (USA).

41. Accepted for publication June 7, 1971. 